\title{
PENINGKATAN KETERAMPILAN SOSIAL ANAK USIA DINI MELALUI PERMAINAN TRADISIONAL
}

\author{
Desi Rahayu ${ }^{1}$ \\ Solihin Ichas $^{2}$ \\ Ai Sutini ${ }^{3}$
}

\begin{abstract}
ABSTRAK
Penelitian Tindakan Kelas ini dilaksanakan untuk memperbaiki masalah keterampilan sosial yang dialami oleh anak kelompok B1 TK Alam Nusantara Kecamatan Cileunyi Kabupaten Bandung, yakni kurangnya dalam berinteraksi dan bersikap kerjasama saat melakukan kegiatan yang dilakukan secara bersama-sama. Hal ini disebabkan karena kurangnya guru dalam melakukan pembiasaan, rangsangan dan stimulus kepada anak yang didalam pembelajarannya mengandung unsur meningkatkan keterampilan sosial anak, serta kurangnya kreativitas dalam menggunakan media dan metode pembelajaran. Tujuan penelitian ini yaitu (1) untuk mengetahui gambaran tentang keterampilan sosial anak usia dini melalui permainan tradisional, (2) untuk mengetahui hasil peningkatan keterampilan sosial anak usia dini setelah mengikuti permainan tradisional. Metode penelitian yang digunakan yaitu Penelitian Tindakan Kelas (PTK) model Elliot dengan tiga siklus dan setiap siklusnya terdiri dari tiga tindakan dengan teknik pengumpulan data berupa penilaian proses, observasi, catatan lapangan dan dokumentasi. Berdasarkan data yang diperoleh dapat diketahui bahwa hasil keterampilan sosial anak melalui permainan tradisional mengalami peningkatan dari siklus 1 sampai siklus 3 . Pada siklus 1 indikator 1 dengan persentase 12,53\%, indikator 2 dengan persentase 19,93\%, dan indikator 3 dengan persentase 19,93\%. Pada siklus 2 indikator 1 dengan persentase 19,39\%, indikator 2 dengan persenatse 32,42\%, dan indikator 3 dengan persentase $26,06 \%$. Selanjutnya pada siklus 3 indikator 1 dengan persentase 54,74\%, indikator 2 dengan persentase $49,78 \%$, dan indikator 3 dengan persentasi $60,25 \%$. Hasil penelitian ini membuktikan bahwa melalui permainan tradisional dapat meningkatkan keterampilan sosial anak usia dini.
\end{abstract}

Kata Kunci: Keterampilan Sosial Anak Usia Dini, Permainan Tradisional

\footnotetext{
${ }^{1}$ desi.rahayu @student.upi.edu

${ }^{2}$ Dosen Kampus UPI Cibiru

${ }^{3}$ Dosen Kampus UPI Cibiru
} 


\section{A. PENDAHULUAN}

Pentingnya sebuah pendidikan yang di mulai sejak dini, akan menjadikan anak-anak kita menjadi anak yang cerdas sehingga apa yang diinginkan dan dicita- citakan dapat diraih dan tercapai. Dengan pendidikan yang diberikan, diharapkan anak dapat tumbuh kembang sesuai dengan potensi yang dimilikinya sehingga kelak dapat menjadi anak bangsa yang diharapakan dan berguna karena pendidikan tersebut dapat memfasilitasi pertumbuhan dan perkembangan anak secara optimal.

Anak usia dini merupakan seseorang individu yang sedang mengalami pertumbuhan dan perkembangan secara pesat yang dilakukan melalui berbagai pemberian rangsangan pendidikan untuk membantu agar anak tersebut dapat menyesuaikan diri dengan lingkungnnya dan memiliki kesiapan untuk memasuki pendidikan ke jenjang yang selanjutnya. Salah satu lembaga yang ada di Indonesia yaitu lembaga Pendidikan Anak Usia Dini, dimana penyelenggaraan Pendidikan Anak Usia Dini ini dapat dilakukan dalam bentuk formal, nonformal dan informal. Berdasarkan UU RI No. 20 Tahun 2003 tentang Sistem Pendidikan Nasional pasal 28 Bab 1 Pasal 1, Butir 14 (dalam Sujiono, 2009, hlm. 8) menyatakan bahwa: Pendidikan Anak Usia Dini adalah suatu upaya pembinaan yang ditujukan kepada anak sejak lahir sampai dengan usia 6 tahun yang dilakukan melalui pemberian rangsangan pendidikan untuk membantu pertumbuhan dan perkembangan jasmani dan rohani agar anak memiliki kesiapan dalam memasuki pendidikan lebih lanjut. Dengan begitu, anak yang berada pada usia 0-6 tahun merupakan masa Golden Age atau dapat disebut dengan masa keemasan, dimana pada masa tersebut berbagai potensi yang dimiliki oleh seorang anak dapat berkembang secara optimal baik dalam aspek kognitif, bahasa, fisik motorik, moral agama, seni maupun sosial emosionalnya. Setiap anak memiliki potensi yang berbeda-beda, seperti hal-hal yang lebih spesifik yang berada pada diri anak tampak lebih jika dibandingkan dengan anak seusianya. Potensi-potensi tersebut misalnya anak sudah mampu berjalan ataupun berbicara pada usia yang sangat dini, sudah mampu berkomunikasi dengan baik, bisa menceritakan suatu kejadian (cerita) dengan cukup jelas, mempunyai daya ingat yang tinggi dan kreativitas yang bagus. Agar potensi yang dimiliki oleh seorang anak tersebut dapat berkembang secara optimal, maka sebagai orang tua atau pendidik terlebih dahulu harus mengenali potensi yang ada pada diri anak, berikan stimulusstimulus yang tepat, arahkan kemampuan yang ada pada diri anak, dampingi dalam setiap aktivitasnya, dan berikan dukungan penuh sehingga anak merasa nyaman dan juga orangtua harus memfasilitasinya sesuai dengan perkembangan dan kebutuhannya. Oleh karena itu, pendidikan merupakan bekal bagi anak untuk mengembangkan berbagai potensi yang dimiliknya. Lingkungan sekeliling anak juga seperti keluarga, sekolah dan masyarakat sekitar sangat penting untuk membantu dan memeberikan berbagai stimulus-stimulus kepada anak sebagai upaya pengoptimalan pertumbuhan dan perkembangan yang dimiliki oleh anak. Agar sama rata antara stimulus yang diberikan oleh pendidik dengan respon anak tersebut, maka proses pembelajaran dan perlakuan yang dilakukan oleh pendidik dan lingkungan sekitar harus sesuai dengan karakteristik perkembangan anak.

Ada beberapa aspek yang harus dikembangkan pada diri anak dalam pendidikan anak usia dini antara lain yaitu aspek kognitif, bahasa, fisik motorik, seni, moral agama dan sosial emosional. Dalam aspek sosial mencakup beberapa sikap diantaranya sikap peduli, bekerjasama, empati, simpati , saling menghargai, saling menghormati, tenggang rasa, berlapang dada dan lainnya. Sehingga keterampilan sosial yang dimiliki oleh seorang anak perlu dikembangkan dari sejak dini karena proses keterampilan sosial tidak terbentuk secara tiba-tiba, akan tetapi pembiasaan yang dilakukan dari lingkungan sekitar anak.

Keterampilan sosial perlu dikembangkan karena pada dasarnya setiap anak akan memerlukan bantuan orang lain atau tidak dapat hidup sendiri dan anak tersebut akan hidup menjadi manusia sosial yang harus berinteraksi dengan yang lainnya. Namun, dalam kenyataanya masih banyak anakanak yang tidak dapat bersosialisasi, berinteraksi dan berkomunikasi dengan orang lain. Oleh karena itu, anak harus memiliki keterampilan sosial. Sebagai pendidik dan orang tua atau masyarakat yang ikut serta dalam mendorong terhadap pertumbuhan dan perkembangan anak harus mampu memberikan contoh dan pembiasaan yang baik, karena anak adalah peniru yang ulung sehingga anak tersebut dapat melihat, mendengar, serta merasakan semua perlakuan dan pembiasaan yang diberikan 
oleh lingkungan sekitar yang nantinya akan dibawa hingga dewasa.

Pada penelitian ini, peneliti mencoba menggunakan metode bermain dengan menggunakan teknik permainan tradisional. Permainan tradisional yang digunakan yaitu galah asin/ gobak sodor, boy-boyan dan bakiak.

\section{B. METODE}

Metode yang digunakan dalam penelitian ini yaitu metode Penelitian Tindakan Kelas (PTK). Metode PTK dipilih karena metode ini relevan untuk memperbaiki proses pembelajaran yang tidak sesuai secara berulang sehingga mampu menghasilkan pembelajaran yang lebih baik. Adapun PTK menurut Abidin (2011, hlm 217) "Penelitian yang dilakukan untuk memecahkan masalah, mengkaji langkah pemecahan masalah itu sendiri, dan atau memperbaiki proses pembelajaran secara berulang dan bersiklus."

Bertemali dengan pernyataan di atas, maka desain penelitian yang digunakan dalam penelitian ini yaitu menggunakan model desain Elliot. Dimana pada model desain Elliot ini terdiri dari tiga siklus dengan setiap siklusnya terdapat tiga tindakan.

Partisipan penelitian tindakan kelas ini adalah kelompok B1 yang berjumlah 13 anak dengan 8 anak perempuan dan 5 anak laki-laki. Penelitian tindakan kelas ini dilakukan di TK Alam Nusantara yang terletak di Jl. Cijambe No. 19 Cinunuk Kecamatan Cileunyi Kabupaten Bandung. Adapun instrumen penilaian yang digunakan yaitu instrumen penilaian proses, lembar observasi, catatan lapangan dan dokumentasi yang berupa foto. Dengan teknik analisis data menggunakan analisis data kualitatf, kuantitaif dan triangulasi.

Berdasarkan penelitian yang telah dilaksanakan dengan menggunakan permainan tradisional galah asin/ gobak sodor, boy-boyan dan bakiak mulai dari siklus 1, siklus 2 dan siklus 3, dapat terlihat peningkatan dari setiap siklusnya. Dengan melalui kegiatan bermain ini anak dapat mengembangkan beberapa sikap yang dimilikanya seperti yang dipaparkan oleh Nugraha \& Rachmawati (2008, hlm. 1.21) yaitu:

1) Sikap sosial

2) Belajar berkomunikasi

3) Belajar mengorganisasi

4) Lebih menghargai orang lain dan perbedaan-perbedaan

Untuk lebih jelas peningkatan tersebut dapat dilihat setiap siklusnya pada grafik berikut.

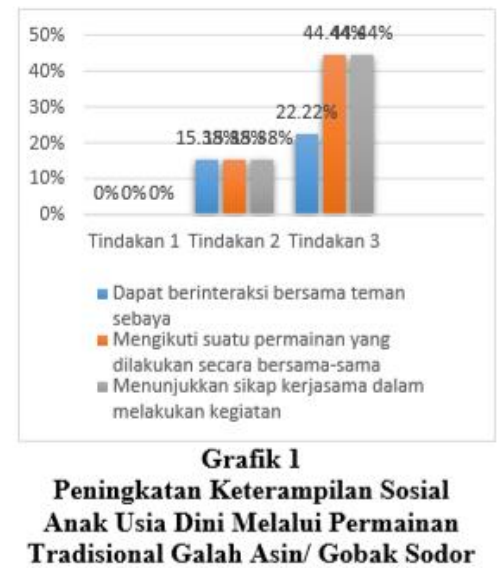

Berdasarkan grafik di atas dapat diketahui bahwa tingkat pencapaian indikator siklus 1 pada hasil keterampilan sosial anak melalui permainan tradisional galah asin/gobak sodor ini belum sesuai dengan pencapaian yang diharapakan oleh peneliti. Terlihat selama kegiatan berlangsung beberapa anak yang tidak berinteraksi, tidak mau mengikuti permainan, mau mengikuti permainan tapi tidak sesuai dengan aturan, kurangnya percaya diri, dan kurangnya kerjasama ketika permainan berlangsung. Hal ini disebabkan karena mood anak yang sedang tidak stabil. Maka dari itu, peneliti perlu memperbaiki proses pembelajaran ataupun media yang digunakan untuk meningkatkan keterampilan sosial anak.

Adapun pada siklus 2 dengan menggunakan permainan tradisional boy- boyan dimana pada 
permainan ini menggunakan media genteng dan bola yang berbeda pada setiap siklusnya. Untuk awal kegiatan sama halnya seperti tindakan sebelumnya peneliti menjelaskan terlebih dahulu cara dan aturan mainnya, setelah itu memberikan contoh. Selama kegiatan berlangsung anak-anak antusias untuk mengikutinya, namun dalam hal pengkondisian masih kurang terkondisikan. Hal tersebut diantisipasi dengan pemberian reward bagi anak yang dapat mengikuti kegiatan dengan baik dan memberikan punishment bagi anak yang susah dikondisikan, seperti yang dikemukakan oleh Bandura (dalam Suyono \& Hariyanto, 2014, hlm. 66) bahwa dalam melakukan pengkondisian dapat dilakukan dengan pemberian reward dan punishment, dimana seorang individu akan berfikir dan memutuskan prilaku sosial mana yang perlu dilaksanakan. Terlihat pada siklus 1 anak belum mampu untuk berinteraksi tetapi berbeda pada siklus 2 ini anak sudah mampu berinteraksi sedikit demi sedikit meskipun dalam aspek kerjasamanya masih kurang.

Selanjutnya pada tindakan 2 anak- anak masih terlihat antusias dan sudah mengerti dengan cara serta aturan mainnya. Dengan adanya aturan yang ditetepkan kepada anak ini untuk menanamkan sikap saling menghargai, saling tolong menolong dan saling kerjasama. Hal ini sejalan dengan pendapat Ibung (2009, hlm. 9) bahwa "Penjelasan peraturan berguna untuk anak mengerti alasan suatu aturan diberlakukan. Jika anak mengerti diharapkan anak akan menanamkan hal tersebut kedalam dirinya sehingga tindakan yang diharapkan menjadi otomatis yang akan dilakukan oleh anak secara mandiri."

Pada tindakan 3 anak sangat antusias dan semangat untuk mengikuti permainan ini terlihat pada tindakan 3 ini anak sudah mulai berinteraksi, mau mengikuti permainan dan sesuai dengan aturan serta sudah adanya kerjasama dengan teman yang lainnya meskipun belum mampu mencapai indikator yang telah ditetapkan.

Adapun hasil penilaian proses pada siklus 2 yaitu sebagai berikut.

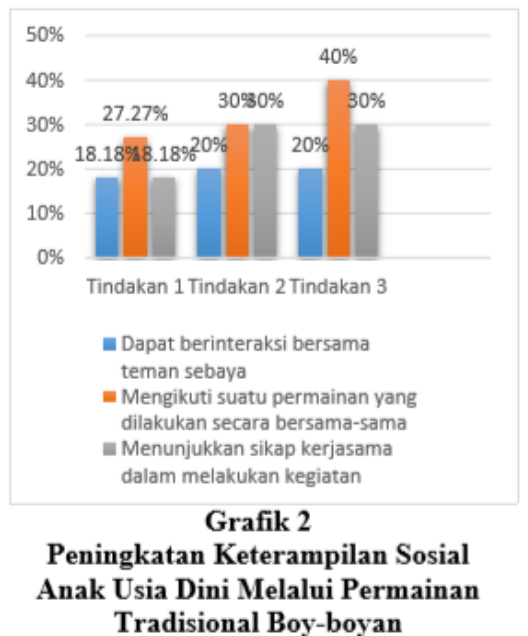

Berdasarkan grafik di atas dapat diketahui bahwa pencapaian indikator hasil keterampilan sosial mengalami peningkatan. Pada siklus 2 terlihat sebagian anak sudah mampu berinteraksi, mau mengikuti permainan sesuai dengan aturan yang dilakukan secara bersama- sama, namun pada tindakan 3 dalam indikator menunjukkan sikap kerjasama mengalami penurunan dari tindakan sebelumnya dikarenakan 3 orang anak tidak sekolah dan masih terdapat anak yang belum bisa bekerjasama. Maka dari itu, peneliti perlu membuat permainan serta media yang lebih menarik lagi agar keterampilan sosial anak dapat meningkat.

Selanjutnya pada siklus 3 permainan tradisional yang digunakan yaitu permainan bakiak, dimana permainan ini membutuhkan interaksi, konsentrasi dan kerjasama. Permainan bakiak ini dapat meningkatkan keterampilan sosial anak, terlihat dari pencapaian yang maksimum selama kegiatan berlangsung dan sesuai dengan indikator yang telah ditetapkan. Pada siklus 3 ini permaian bakiak dan media yang digunakan lebih menarik sehingga membuat anak antusias untuk mengikutinya. Dalam siklus 3 ini pun anak sudah bisa dikondisikan. 
Berdasarkan hasil temuan pada siklus 3 tindakan 1, 2 dan 3 bahwa ketika kegiatan berlangsung anak sangat antusias serta menyukai permainan tersebut dikarenakan permainan ini baru dikenalkan kepada anak dan permainan ini bersifat kelompok yang mendukung adanya sosialisasi antara teman. Sejalan dengan Catron dan Allen (dalam Mutiah, 2010, hlm. 149) bahwa bermain mendukung perkembangan sosialisasi dalam hal sebagai berikut. (1) Interaksi sosial. (2) Kerjasama. (3) Menghemat sumber daya. (4) Peduli terhadap orang lain.

Namun pada saat peneliti menjelaskan mengenai cara dan aturan mainnya Sandi, Fachri dan Taufan tidak bisa diam, karena memainkan bakiak yang sudah dipersiapakan oleh peneliti. Hal ini dikarenakan anak tersebut memiliki tipe kinestetik seperti yang diungkapkan oleh Jannah (2013, hlm. 79) yaitu "Sulit berdiam diri atau duduk manis, selalu ingin bergerak".

Adapun hasil penilaian proses pada siklus 3 sebagai berikut.

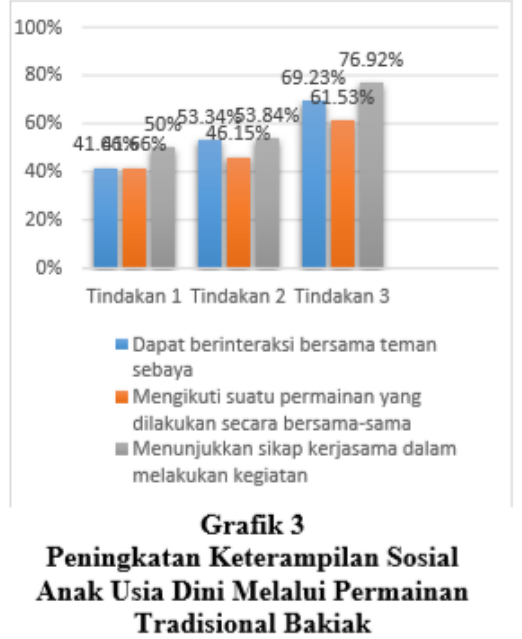

Berdasarkan grafik di atas, dapat diketahui bahwa pencapaian indikator hasil keterampilan sosial anak melalui permainan tradisional pada siklus 3 ini meningkat sesuai dengan pencapaian yang diharapkan oleh peneliti. Pada siklus 3 terlihat perolehan yang meningkat yaitu pada indikator 1 dan 3 yaitu dapat berinteraksi bersama teman sebaya dan menunjukkan sikap kerjasama dalam melakukan kegiatan sudah mencapai hasil yang optimal.

Berikut ini akan disajikan grafik rata-rata hasil penilaian proses keterampilan sosial anak melalui permainan tradisional pada siklus 1, 2 dan 3 .

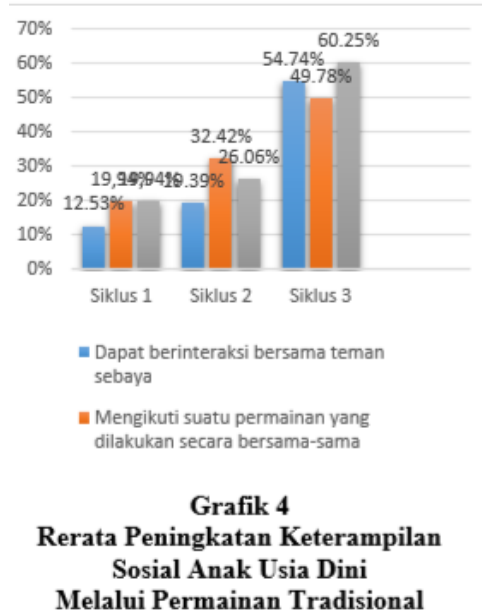

Berdasarkan grafik di atas, dapat diketahui hasil penilaia proses keterampilan sosial anak melalui permainan tradisional mengalami peningkatan dari siklus 1 sampai siklus 3 . Pada siklus 1 dengan indikator dapat berinteraksi bersama teman sebaya mendapatkan 12,53\%. Berikutnya indikator mengikuti suatu permainan yang dilakukan secara bersama-sama mendapatkan 19,93\%. 
Lalu pada indikator menunjukkan sikap kerjasama yang dilakukan secara bersama-sama mendapatkan hasil yang sama dengan indikator sebelumnya yaitu 19,93\%.

Pada siklus 2 dengan indikator dapat berinteraksi bersama teman sebaya mendapatkan 19,39\%. Berikutnya indikator mengikuti suatu permainan yang dilakukan secara bersama-sama mendapatkan $32,42 \%$. Sedangkan pada indikator menunjukkan sikap kerjasama yang dilakukan secara bersama-sama mendapatkan $26,06 \%$.

Selanjutnya pada siklus 3 dengan indikator dapat berinteraksi bersama teman sebaya mendapatkan $54,74 \%$. Berikutnya indikator mengikuti suatu permainan yang dilakukan secara bersama-sama mendapatkan 49,78\%. Dan pada indikator menunjukkan sikap kerjasama yang dilakukan secara bersama-sama mendapatkan $60,25 \%$.

\section{KESIMPULAN}

Berdasarkan hasil penelitian yang telah dilaksanakan di kelompok B1 Tk Alam Nusantara untuk meningkatkan keterampilan sosial anak usia dini melalui permainan tradisional yang dilakukan sebanyak 3 siklus, maka dapat disimpulkan bahwa proses kegiatan permainan tradisional yang telah diterapkan oleh peneliti ternyata efektif untik peningkatan keterampilan sosial anak usia dini disetiap siklusnya. Hal ini dapat dilihat bahwa anak antuias, semangat serta menyukai permainan yang telah disediakan oleh peneliti. Jenis permainan tradisional itu sendiri diantaranya yaitu permainan galah asin/ gobak sodor, boy-boyan dan bakiak. Pada setiap permainan peneliti menjelaskan terlebih dahulu bagaimana cara serta aturan mainnya, setelah itu anak dikelompokkan menjadi beberapa kelompok dan setelah anak mengerti cara dan aturan mainnya, maka anak-anak tersebut melakukan permainan sesuai dengan intruksi yang diberikan. Sebagai perbaikan yang telah dilaksanakan pada kegiatan sebelumnya, peneliti menggunakan media yang semenarik mungkin agar anak tertarik dan tidak mudah bosan untuk mengikuti permainan-permainan tersebut. Dalam permainan ini anak belajar berkomunikasi, bekerjasama, percaya diri dan aspek sosial lainnya karena permainan ini adalah permainan yang bersifat kelompok, sehingga secara tidak langsung anak kelompok B1 TK Alam Nusantara mengalami peningkatan yang lebih baik terhadap keterampilan sosialnya.

Selanjutnya untuk hasil analisis temuan penelitian dalam peningkatan keterampilan sosial anak usia dini melalui permainan tradisional kelompok B1 di TK Alam Nusantara pada setiap siklusnya secara bertahap mengalami peningkatan. Terlihat selama proses kegiatan berlangsung beberapa anak awalnya tidak berinteraksi, tidak mau mengikuti permainan, serta tidak menunjukkan sikap kerjasama dalam melakukan kegiatan, adanya peningkatan yang baik. Penggunaan permainan tradisional yang bersifat kelompok/ kooperatif mampu merubah dan dapat memfasilitasi anak yang kesulitan dalam berinteraksi dan berkomunikasi dengan lingkungannya. Setelah menggunakan permainan tradisional anak dapat berinteraksi, mau mengikuti permainan, percaya diri, menunjukkan sikap kerjasama dan menunjukkan keterampilan sosial lainnya. Adapun hasil proses keterampilan sosial anak usia dini melalui permainan tradisional, hal ini terlihat dalam rata-rata presentase perolehan bintang 4 yang terus meningkat dari setiap siklusnya. Siklus 1 dengan indikator dapat berinteraksi bersama teman sebaya terdapat $12,53 \%$, indikator 2 mengikuti permainan yang dilakukan secara bersama-sama terdapat 19,94\%, indikator 3 menunjukkan sikap kerjasama dalam melakukan kegiatan terdapat 19,94\%. Pada siklus 2 yang mencapai indikator 1 terdapat 19,39\%, lalu yang mencapai indikator 2 terdapat 32,42\%, sedangkan yang mencapai indikator 3 terdapat 26,06\%. Kemudian pada siklus 3 yang mencapai indikator 1 terdapat 54,74\%, indikator 2 terdapat 49,78\% dan yang mencapai indikator 3 terdapat $60,25 \%$.

\section{DAFTAR PUSTAKA}

Abidin, Yunus. (2011). Penelitian pendidikan dalam gamintan pendidikan dasar dan PAUD. Bandung: Rizqi Press.

Nugraha \& Rachmawati. (2008). Metode pengembangan social emosional. Jakarta: Universitas Terbuka.

Sujiono. (2009). Konsep dasar pendidikan anak usia dini. Jakarta: PT Macanan Jaya Cemerlang. Mutiah, Diana. (2010). Psikologi bermain anak usia dini. Jakarta: Kencana.

Ibung, D. (2009). Mengembangkan nilai moral pada anak. Jakarta: PT. Alex Media Komputindo. 
Suyanto \& Hariyanto. (2014). Belajar danpembelajaran. Bandung: PT. Remaja Rosdakarya.

Jannah, A.L. (2013). Kesalahan-kesalahan guru PAUD yang sering dianggap sepele. Yogyakarta:

Diva Press. 